\title{
Discovery and Geology of the Nabberu Kimberlite Province, Western Australia.
}

Shee, S.R. ${ }^{1}$, Vercoe S.C ${ }^{2}$, Wyatt B.A. ${ }^{1}$, Campbell A.N. ${ }^{3}$, Colgan E.A. ${ }^{4}$, and Hwang P.H. ${ }^{5}$

1. Stockdale Prospecting Limited, PO Box 126, South Yarra, VIC 3141

2. Stockdale Prospecting Limited, 21 Ballantyne Road, Kewdale, Perth, WA 6105

3. E102 Malcha Marg, Chanakyapuri, New Delhi 110 021, India.

4. 10 Oxley Road, Forrestdale, Perth, WA 6112

5. 96 Davy Street, Booragoon, Perth, WA 6154

\section{Location and Regional Geology}

During the past ten years Stockdale Prospecting Limited (SPL), the exploration arm of De Beers Consolidated Mines in Australia, has enjoyed considerable technical success in locating kimberlites in Western Australia. New bodies have been found on the western Bangemall Basin (Ullawarra, Barlee Range, Illirrie Bore), on the Eastern Goldfields of the Yilgarn Craton (Turkey Well, Granite Creek, Red Well, Teutonic Bore, Rainbow, Wilbah, Melita) and on the Marymia Dome (Nabberu) see Figure 1. This abstract describes the discovery and geology of the Nabberu kimberlite province, which lies on the NE flank of Archaean granitoid rocks of the Marymia Dome. Proterozoic sedimentary rocks of the Nabberu Basin on-lap the NE/SW trending southern margin of the dome and flank the northern margin of the Archaean Yilgarn Block. The area is part of the Capricorn Orogen, a major tectonic belt separating the Yilgarn and Pilbara Cratons. The internal structure of the Capricorn Orogen is interpreted to reflect collision between the Yilgarn and Pilbara Cratons. Within the Marymia Dome, the dominant NE trending lineaments are aligned with its faulted southern margin, along which thrusting and shearing has resulted in uplift of the dome by as much as $5 \mathrm{~km}$ (Bunting et al., 1977).

\section{Exploration History and Methodology}

In 1986, Western Mining Corporation discovered four ultramafic lampropyhric (damkjernite and allikite) intrusive bodies near Bulljah Pool in central Western Australia (Hamilton and Rock, 1990; Hamilton, 1992). These marginally diamondiferous rocks of deep mantle origin have many affinities with classical kimberlites. Their discovery prompted SPL to start reconnaissance sampling over well-drained areas on the Nabberu 1:250,000 sheet (SG51-05). Stream sampling between 1987 and 1989 showed the Eastern Creek drainage of the Marymia sub-area to be of particular interest with the recovery of abundant kimberlitic chromites. An aeromagnetic survey of SPL exploration licences in the Eastern Creek area revealed the presence of 52 magnetic anomalies (MA01-52). In 1990 these anomalies were followed-up by ground magnetics, heavy mineral and geochemical sampling, and where warranted, by drilling. Twelve kimberlites, four of which are diamondiferous but sub-economic and numerous related "lamprophyric" rocks were discovered during 1991 and 1992. The largest kimberlite, Nabberu 01, a diamondiferous body, was discovered after work on magnetic anomaly MA47 and TM anomaly TM91. This body was the recipient of most of the follow up work which included heavy mineral and geochemical sampling, geological mapping, diamond drilling, SIROTEM traverses, a gravity survey and a bulk sample for diamonds. The kimberlites, found by airborne magnetics, are larger than the lamprophyres, which were found by ground mapping. These bodies, all of which are small pipes $(<2 \mathrm{ha})$ or dykes, comprise part of a new kimberlite province (Figure 2). 

Figure 1. Locations of kimberlites and related rocks, Western Australia. 1 Nabberu (SPL), 2 Jewill (CRA), 3 Bulljah (WMC), 4 Ullawarra (SPL), 5 Barlee Range (SPL), 6 Illirrie Bore (SPL), 7 ETL (Diamond Ventures), 8 Gifford Creek, 9 Wandagee (CRA, SPL), 10 Melrose Akbar (WMC, SPL), 11 Turkey Well (SPL), 12 Granite Creek (SPL), 13 Red Well (SPL), 14 Teutonic Bore (SPL), 15 Rainbow (SPL), 16 Wilbah (SPL), 17 Melita (SPL), 18 Mt Weld, 19 Placer Pacific, 20 Lara (WMC, SPL), 21 Ponton Creek / Cundeelee, 22 Norseman (SPL).

Figure 2. Location of the Nabberu kimberlites, Marymia Dome, Western Australia.

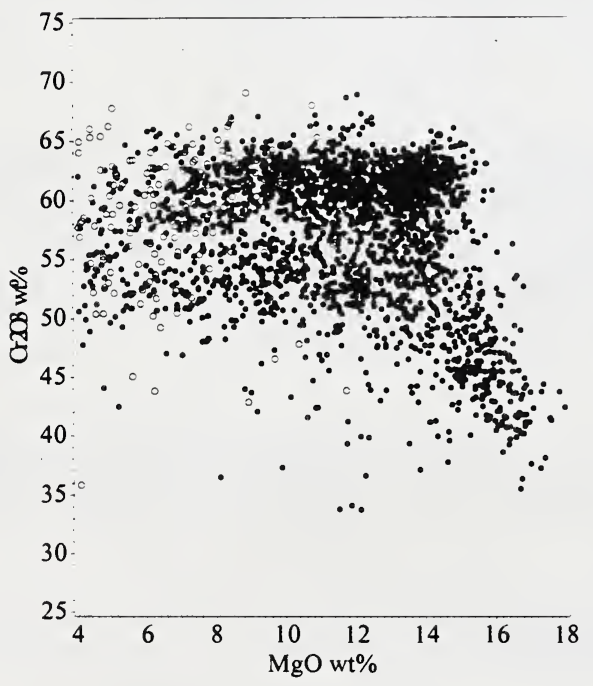

$\mathrm{ZnO} w t \%$ low $(0-0.4) \quad 000$ high $(>0.4)$

Figure 3. $\mathrm{Cr}_{2} \mathrm{O}_{3}$ vs $\mathrm{MgO}$, Nabberu 01 spinels.
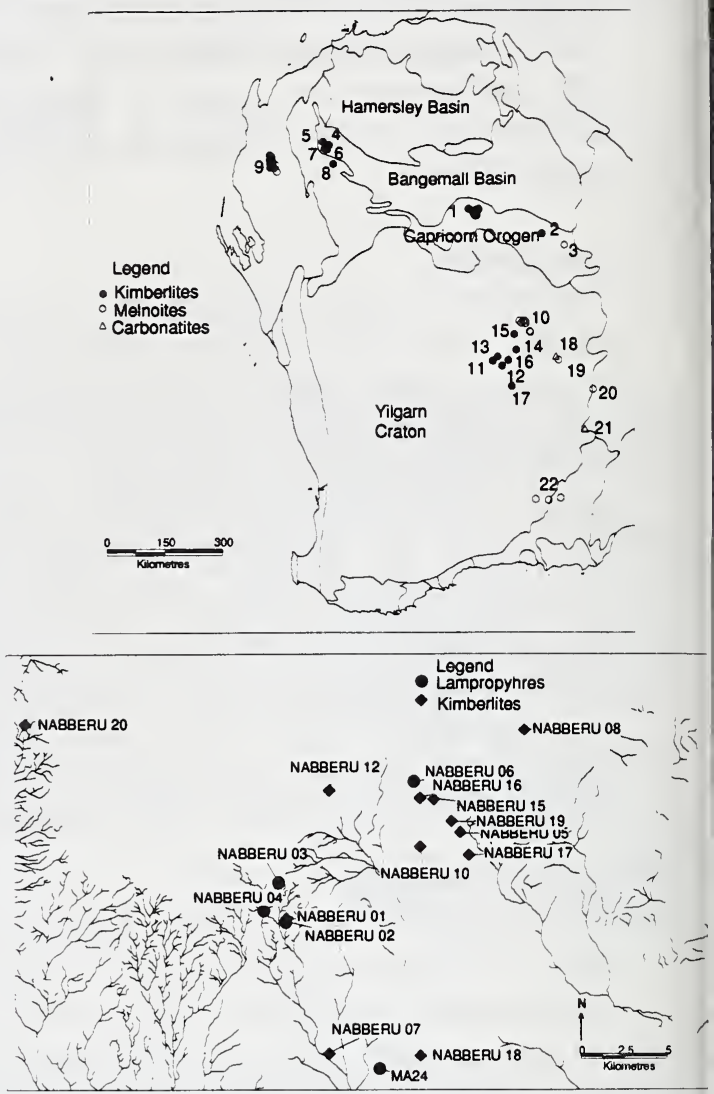

75

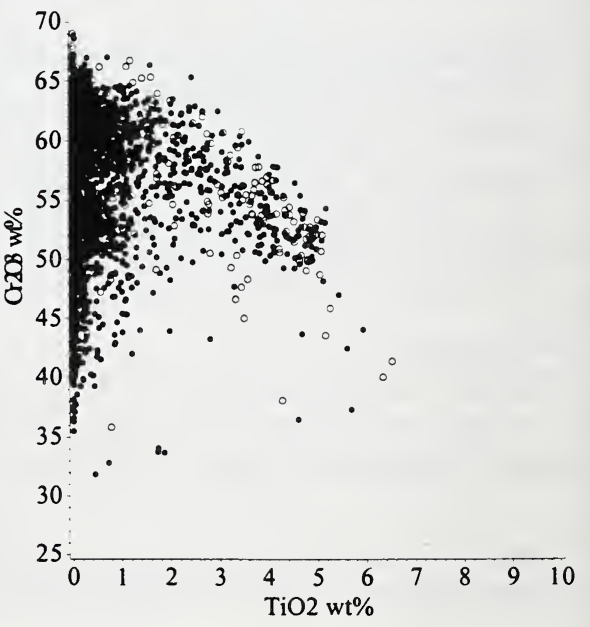

$\mathrm{ZnO}$ wt\% $\cdots$ low $(0-0.4) \quad 000$ high $(>0.4)$

Figure 4. $\mathrm{Cr}_{2} \mathrm{O}_{3}$ vs $\mathrm{TiO}_{2}$, Nabberu 01 spinels. 